\title{
PENDIDIKAN KARAKTER DALAM PERSPEKTIF ISLAM DAN STRATEGI IMPLEMENTASINYA
}

\author{
Siti Nasihatun \\ Badan Penelitian dan Pengembangan dan Pendidikan dan Pelatihan - Kementerian Agama \\ Email: nanaloryn@gmail.com \\ https://doi.org/10.36052/andragogi.v7i2.100 \\ Diterima: 11 Oktober 2019 | Disetujui: 12 Desember 2019 | Dipublikasikan: 30 Desember 2019
}

\begin{abstract}
Abstrak
Tujuan penelitian ini adalah untuk menganalisis pendidikan karakter dalam perspektif Islam dan bagaimana cara mengimplementasikannya. Metode penelitian yang digunakan adalah metode kualitatif dengan pendekatan library reseach. Hasil penelitian in menunjukkan bahwa pendidikan karakter memiliki makna lebih tinggi daripada pendidikan moral, oleh karenanya pendidikan karakter bukan hanya mengajarkan benar salah, tetapi sekaligus menanamkan kebiasaan (habituation) tentang yang baik sehingga siswa menjadi paham, mampu merasakan, dan mau melakukan apa yang baik. Dalam pandangan Islam, karakter itu disebut dengan akhlak. Komponen pendidikan akhlak atau kepribadian meliputi: pengetahuan, sikap, dan perilaku dan identik dengan ajaran agama Islam itu sendiri yang bersumber dari Alquran dan al-Hadis. Dengan demikian, dapat dinyatakan bahwa pendidikan karakter perspektif Islam merupakan sistem perilaku yang diwajibkan dalam agama Islam yang tertuang melalui nash alquran dan Hadis Rasulullah Saw. Implementasi pendidikan karakter dalam Islam menurut hadis Rasulullah Saw, dapat diklasifikasikan dalam 6 tahapan yaitu: 1) Tauhid (dimulai sejak 0-2 tahun); 2) Adab (5-6 tahun); 3) Tanggung jawab diri (7-8 tahun); 4) Caring-Peduli (9-10 tahun); 5) Kemandirian (11-12 tahun); dan 6) Bermasyarakat (13 tahun ke atas).
\end{abstract}

Kata Kunci: karakter, pendidikan karakter perspektif islam, implementasi karakter islami

\begin{abstract}
The purpose of this study is to analyze character education in an Islamic perspective and how to implementation. The research method used is a qualitative method with a library research approach. The results of this study indicate that character education has a higher meaning than moral education, therefore character education not only teaches right and wrong, but at the same time instills habits (habituation) about good so that students become aware, able to feel, and want to do what is good. In the Islamic view, that character is called morals. Components of moral education or personality include: knowledge, attitudes, and behavior and are identical with the teachings of Islam itself which are sourced from the Qur'an and al-Hadith. Thus, it can be stated that the Islamic perspective of character education is a system of behavior that is required in the Islamic religion as stipulated through the Qur'an and al-Hadith Rasulullah saw. Implementation of character education in Islam according to the hadith of the Messenger of Allah, can be classified in 6 stages, namely: 1) Tawhid (starting from 0-2 years); 2) Adab (5-6 years); 3) Self responsibility (7-8 years); 4) Caring-Caring (9-10 years); 5) Independence (11-12 years); and 6) Community (13 years and above).
\end{abstract}

Keywords: character, islamic perspective character education, implementation of islamic character 


\section{PENDAHULUAN}

$S$ ejak 2500 tahun yang lalu, Socrates telah berkata bahwa tujuan mendasar dari pendidikan adalah untuk membuat seseorang menjadi good dan smart. Dalam sejarah Islam, 1400 tahun yang lalu Rasulullah Saw. diutus ke muka bumi ini tiada lain untuk menyempurnakan akhlak manusia menjadi akhlakul karimah (akhlak yang baik).

Para pakar pendidikan bersepakat bahwa pembentukan karakter menjadi tujuan utama pendidikan, walaupun dalam perjalanannya pembentukan karakter sempat agak terlupakan di sekolah. Tokoh pendidikan barat yang mendunia seperti Kirkpatrick, Lickona, Brooks, dan Goble seakan menggemakan kembali apa yang pernah disampaikan oleh Socrates dan Rasulullah Saw. bahwa moral, akhlak atau karakter adalah tujuan yang tak terhindarkan dari dunia pendidikan. Selanjutnya, Martin Luther King berpendapat "Intellegence plus character that is true aim of education." Kecerdasan ditambah karakter itulah tujuan yang benar dari pendidikan.

Menurut analisis Thomas Lickona sebagaimana dirangkum oleh Howard, bangkitnya logika positivisme yang menyatakan bahwa tidak ada kebenaran moral dan tidak ada sasaran benar dan salah, telah menenggelamkan pendidikan moral dari dunia pendidikan. Selain itu, pemikiran relativitas moral dengan pandangannya yang menyatakan bahwa semua nilai adalah relatif, berpengaruh terhadap terlupaknnya pendidikan karakter. Paham personalisme yang menyatakan tentang individu bebas memilih nilai-nilainya sendiri dan tidak bisa dipaksakan oleh siapapun serta meningkatnya paham pluralisme yang mempertanyakan nilainilai siapakah yang diajarkan semakin melengkapi alasan penolakan pendidikan karakter. Sekularisme masyarakat juga berkontribusi dalam menumbuhkan ketakutan untuk mengajarkan moralitas di sekolah karena khawatir dianggap sebagai pengajaran agama. Hal ini terutama terjadi untuk penyelenggaraan pendidikan di negara-negara maju dan sekuler

Di Indonesia, sejarah pendidikan moral atau karakter dapat ditelusuri dari keterkaitannya dengan kewarganegaraan (citizenship). Pada awal kemerdekaan, dikenal dengan pendidikan dan pengajaran budi pekerti yang menanamkan peserta didik tentang asas-asas moral, etika, dan etiket yang melandasi sikap dan tingkah laku dalam pergaulan sehari-hari. Memasuki era demokrasi terpimpin di bawah kepemimpinan Soekarno tahun 1960-an pendidikan karakter dikampanyekan hebat dan dikenal dengan national and character building. Pada masa pemerintahan orde baru, dikenal dengan penataran P4 (Pedoman Penghayatan dan Pengamalan Pancasila) yang menjadi mata pelajaran wajib sekaligus penataran yang bersifat wajib pula. Selanjutnya, upaya pembentukan karakter bangsa melalui mata pelajaran berlabel Pancasila terus dilakukan dengan pendekatan indoktrinasi sampai akhir pemerintahan orde baru. Pada masa reformasi, sekitar tahun 2004-2006 digulirkan kurikulum berbasis kompetensi (KBK) yang 
mengawali lahirnya kembali pelajaran budi pekerti.

Selanjutnya, pendidikan karakter di sekolah-sekolah mulai mendapatkan perhatian kembali dari pemerintah sebagai program utama pendidikan. Kementerian Pendidikan Nasional mencanangkan visi penerapan pendidikan karakter terutama mulai tahun tahun 2010-2014. Untuk selanjutnya, pendidikan karekter masuk ke dalam muatan kurikulum 2013 seperti tertuang dalam mata pelajaran pendidikan agama dan budi pekerti/karakter.

Penerapan pendidikan karakter memerlukan pemahaman yang jelas tentang konsep pembentukan karakter dan pendidikan karakter itu sendiri. Melalui pijakan konsep yang jelas dan pemahaman yang komprehensif, visi pendidikan karakter diharapkan dapat diimplementasikan dengan baik dan berdampak pada pembentukan karakter bangsa yang unggul.

Realitas di lapangan, kompetensi lulusan sekolah yang ditampilkan sebagai output pendidikan masih belum sesuai dengan tujuan pendidikan. Masih ditemukannya siswa yang terlibat tawuran, narkoba dan seks bebas menjadi PR tersendiri bagi dunia pendidikan khususnya pemerintah dan masyarakat untuk memformulasikan kembali pendidikan yang sesuai dengan tuntutan zaman dan tetap meneguhkan karakter bangsa yang unggul. Sekolah bertanggung jawab terhadap pembentukan karakter yang baik bagi para siswanya.

Pendidikan karakter yang bersumber dari nilai-nilai karakter budaya bangsa diasumsikan dapat mengatasi berbagai persoalan bangsa terutama melalui jalur pendidikan dalam rangka membentuk kepribadian dan watak bangsa asli Indonesia dan menjadi perekat dalam kehidupan berbangsa dan bernegara. Pendidikan merupakan kunci dalam membentuk karakter anak sejak dini, karena hakikat pendidikan tidak hanya sebatas transfer of knowledge akan tetapi juga transfer of values, semua itu dilakukan untuk membangun karakter anak bangsa berkepribadian mulia serta menanggulangi kenakalan remaja dari berbagai penyimpangan sosial.

Pendidikan karakter akan lebih terinternalisasi dengan baik apabila diselaraskan dengan ajaran agama yang dianutnya, mengingat agama merupakan pedoman hidup utama sekaligus ideologi dasar setiap manusia. Agama berperan penting dalam meningkatkan derajat dan martabat manusia dengan mengajarkan hal-hal yang boleh dilakukan dan tidak boleh dilakukan manusia berdasarkan wahyu Tuhan yang maha esa. Kebenaran agama melalui wahyu bersifat mutlak dilakukan oleh para penganutnya. Untuk itu, pendidikan karakter yang bersumber pada nilai-nilai agama akan lebih mendorong manusia untuk melakukannya karena nilai kemutlakan kebenaran yang diyakininya.

Mayoritas penduduk Indonesia adalah muslim. Untuk itu, perlu kiranya pendidikan karakter bagi muslim di Indonesia, diberikan selaras dengan nilai-nilai agama Islam yang bersumber dari kitab sucinya yaitu Alquran dan Hadis. Untuk itu, penelitian ini menjadi penting untuk dilakukan dalam rangka menganalisis konsep pendidikan karakter dalam perspektif Islam dan bagaimana implementasi pendidikan karakter dalam perspektif Islam. 


\section{METODE PENELITIAN}

Penelitian ini menggunakan pendekatan kualitatif dengan metode library reseach (penelitian kepustakaan). Library research (penelitian kepustakaan) merupakan salah satu jenis metode penelitian kualitatif yang dilaksanakan dengan cara menggunakan literaur (kepustakaan) baik berupa buku, catatan, maupun laporan hasil penelitian dari penelitian terdahulu (Hasan, 2002: 11). Dalam penelitian kualitatif, peneliti adalah instrumen kunci. Oleh karena itu peneliti harus memiliki bekal teori dan wawasan yang luas jadi bisa bertanya, menganalisis dan mengkonstruksi objek yang diteliti menjadi lebih jelas. Penelitian ini lebih menekankan pada makna dan terikat nilai. Penelitian kualitatif dilakukan pada kondisi alamiah dan bersifat penemuan.

Secara garis besar, sumber bacaan yang ada di perpustakaan dapat dibedakan menjadi dua kelompok yaitu sumber acuan umum dan sumber acuan khusus. Sumber acuan umum biasanya berisi tentang teori-teori dan konsep-konsep melalui buku-buku teks, ensklopedi, monograp, dan sejenisnya, sedangkan sumber acuan khusus yaitu berupa junal, bulletin penelitian, tesis dan lain-lain (Komidar: 1995). Pada penelitian ini, kedua sumber tersebut digunakan untuk menganalisis permasalahan terkait fokus penelitian yaitu pendidikan karakter perspektif Islam dan implementasinya.

\section{TEMUAN DAN PEMBAHASAN}

\section{Definisi Pendidikan Moral, Pendidikan Akhlak dan Pendidikan Karakter}

Moral berasal dari bahasa Latin "Mores" dan kata jamak dari "Mos" yang artinya adat kebiasaaan. Dalam bahasa Indonesia moral diterjemahkan dengan arti susila. Moral adalah sesuai dengan ide-ide yang umum diterima tentang tindakan manusia mana yang baik dan wajar. Jadi sesuai dengan tindakantindakan yang oleh umum diterima yang meliputi kesatuan sosial atau lingkungan tertentu. Pendidikan moral merupakan pendidikan yang bertujuan untuk mengajarkan nilai-nilai kebaikan dalam kehidupan manusia baik dalam kehidupan pribadi, keluarga dan masyarakat dan sangat normatif (Hamzah: 1983, 14).

Dalam istilah bahasa Arab, moral identik dengan akhlak atau kepribadian seseorang. Akhlak berasal dari bahasa Arab jamak dari "khuluqun" yang berarti budi pekerti, perangai, tingkah laku atau tabiat. Rumusan pengertian akhlak timbul sebagai media yang memungkinkan adanya hubungan baik antara Khalik dan mahluk serta antara mahluk dan mahluk. Akhlak merupakan suatu ilmu yang menjelaskan arti baik dan buruk, menerangkan apa yang seharusnya dilakukan oleh manusia kepada yang lainnya, serta menyatakan tujuan yang harus dituju oleh manusia dalam perbuatan mereka dan menunjukkan jalan untuk melakukan apa yang harus diperbuat. Sedangkan pendidikan akhlak menurut Ibn Miskawaih dan dikutip oleh Abudin Nata adalah upaya ke arah terwujudnya sikap batin yang mampu mendorong secara spontan lahirnya perbuatanperbuatan yang bernilai baik dari seseorang. Dalam pendidikan akhlak ini, kriteria benar dan salah untuk menilai perbuatan yang muncul merujuk pada 
Alquran dan Sunnah Rasul sebagai sumber tertinggi ajaran Islam.

Sedangkan dalam istilah bahasa Latin, moral dan akhlak dapat didefinisikan sebagai karakter atau kepribadian. Karakter berasal dari bahasa Latin "kharacter", "kharassein", "kharax", dalam bahasa Inggris character dan Indonesia "karakter". Dalam bahasa Yunani character berasal dari charassein yang berarti membuat tajam, membuat dalam. Dalam kamus Poerwadarminta, karakter diartikan sebagai tabiat, watak, sifat-sifat kejiwaan, akhlak atau budi pekerti yang membedakan seseorang dengan yang lain. Hermawan Kertajaya (2010: 3) mendefinisikan karakter sebagai ciri khas yang dimiliki oleh suatu benda atau individu. Ciri khas tersebut adalah asli dan mengakar pada kepribadian benda atau individu tersebut dan merupakan mesin pendorong bagaimana seorang bertindak, bersikap, berujar dan merespons sesuatu. Untuk menajamkan karakter seseorang menjadi manusia yang memiliki karakter unggul dan paripurna, salah satu upayanya adalah melalui pendidikan karakter. Pendidikan karakter merupakan upaya sadar dan sungguh-sungguh dari seorang guru untuk mengajarkan nilai-nilai pendidikan kepada siswanya (Samani \& Hariyanto, 2011: 43).

Pendidikan karakter mulai ramai dibicarakan sejak tahun 1990-an. Thomas Lickona dengan bukunya "The Return of Character Education" menjadi awal kebangkitan pendidikan karakter. Definisi karakter menurut Ryan dan Bohlin mengandung tiga unsur pokok yaitu mengetahui kebaikan (knowing the good), mencintai kebaikan (loving the good), dan melakukan kebaikan (doing the good). Pendidikan karakter adalah sebuah upaya untuk membimbing perilaku manusia menuju standar-standar baku. Upaya ini juga memberi jalan untuk menghargai persepsi dan nilai-nilai pribadi yang ditampilkan di sekolah. Fokus pendidikan karakter adalah pada tujuan-tujuan etika, tetapi praktiknya meliputi penguatan kecakapankecakapan yang penting yang mencakup perkembangan sosial siswa.

Dengan mengetahui adanya karakter (watak, sifat, tabiat ataupun perangai), seseorang dapat memperkirakan rekasi-reaksi dirinya terhadap berbagai fenomena yang muncul dalam diri ataupun hubungannya dengan orang lain, dalam berbagai keadaan dan bagaimana cara mengendalikannya. Karakter dan akhlak memiliki definisi yang hampir sama dimana keduanya merupakan suatu tindakan yang terjadi tanpa adanya pemikiran dalam melakukannya/spontan karena sudah tertanam kuat dalam pikirannya dan menjadi sebuah kebiasaan seseorang.

Selanjutnya, definisi tentang budi pekerti. Esensi makna budi pekerti sama dengan pendidikan moral dan pendidikan akhlak. Dalam konteks di Indonesia, pendidikan budi pekerti adalah pendidikan nilai, yakni pendidikan nilai yang luhur yang bersumber dari budaya bangsa Indonesia, dalam rangka membina kepribadian generasi muda. Dalam kamus bahasa Indonesia, kata budi artinya alat batin yang merupakan paduan akal dan perasaan untuk menimbang baik buruk. Budi bermakna juga tabiat, akhlak, watak, orang yang baik. Sedangkan pekerti berarti perangai, tabiat, akhlak, 
watak/perbuatan. Secara operasional, budi pekerti merupakan perilaku yang tercermin dalam kata, perbuatan, pikiran, sikap, perasaan, keinginan, dan hasil karya.

Pendidikan karakter memiliki makna lebih tinggi daripada pendidikan moral, karena pendidikan karakter bukan hanya mengajarkan benar salah, tetapi sekaligus menanamkan kebiasaan (habituation) tentang yang baik sehingga siswa menjadi paham, mampu merasakan, dan mau melakukan apa yang baik. Moral adalah pengetahuan seseorang terhadap hal baik dan buruk. Sedangkan karakter adalah tabiat seseorang yang langsung di-drive oleh otak.

\section{Mekanisme Pembentukan Karakter}

Karakter berasal dari bahasa Yunani, Charasein yang artinya mengukir. Sifat utama ukiran adalah melekat kuat di atas benda yang diukir, tidak mudah usang ditelan waktu atau aus terkena gesekan. Menghilangkan ukiran sama saja dengan menghilangkan benda yang diukir itu. Hal itu dikarenakan, suatu ukiran akan melekat dan menyatu dengan benda yang diukir itu.

Unsur terpenting dalam pembentukan karakter adalah pikiran karena di dalam pikiran terdapat seluruh program yang terbentuk dari pengalaman hidup. Program ini kemudian membentuk kepercayaan yang akhirnya dapat membentuk pola pikir dan mempengaruhi perilakunya. Jika program tersebut tertanam sesuai prinsip-prinsip universal, maka perilakunya berjalan selaras dengan hukum alam dan pada akhirnya akan membawa ketenangan dan kebahagiaan seseorang. Sebaliknya, jika program yang dimiliki tidak sesuai dengan prinsip-prinsip hukum universal, perilakunya akan membawa kerusakan dan penderitaan. Untuk itu, pikiran harus dijaga dengan baik dan mendapatkan perhatian yang serius agar membawa kebahagiaan bagi dirinya.

Joseph Murphy mengatakan bahwa di dalam diri manusia, terdapat satu pikiran yang memiliki ciri berbeda. Untuk membedakan ciri tersebut, maka istilahnya dinamakan dengan pikiran sadar (conscious mind) atau pikiran objektif dan pikiran bawah sadar (subconscious mind) atau pikiran subjectif. Pikiran sadar yang secara fisik terletak di bagian korteks otak bersifat logis dan analisis dengan memiliki pengaruh sebesar $12 \%$ dari kemampuan otak. Sedangkan pikiran bawah sadar secara fisik terletak di medulla oblongata yang sudah terbentuk ketika masih di dalam kandungan. Oleh karena itu, bayi yang baru dilahirkan menangis, dan akan tenang ketika berada dalam dekapan ibundanya karena dia sudah tidak asing lagi detak jantung ibundanya tersebut. Pikiran bawah sadar bersifat netral dan sugestif.

\section{Proses Pembentukan Karakter}

Secara alami, manusia sejak lahir sampai usia tiga atau lima tahun, kemampuan menalar seseorang belum tumbuh sehingga pikiran bawah sadar (subconscious mind) masih terbuka dan menerima apa saja informasi dan stimulus yang dimasukkan ke dalamnya tanpa ada penyeleksian, mulai dari orang tua, dan lingkungan keluarga dan dari merekalah mulai terbangun 
pondasi awal terbentuknya karakter. Pondasi tersebut adalah kepercayaan tertentu dan konsep diri.

Selanjutnya, pengalaman hidup yang berasal dari lingkungan kerabat, sekolah, televisi, internet, buku, majalah, dan berbagai sumber lainnya menghantarkan seseorang memiliki kemampuan yang semakin besar untuk dapat menganalisis dan menalar objek luar. Mulai dari sinilah, peran pikiran sadar (conscious mind) menjadi semakin dominan. Seiring perjalanan waktu, maka penyaringan terhadap informasi yang masuk melalui pikiran sadar menjadi lebih ketat sehingga tidak sembarang informasi yang masuk melalui pancaindera dapat mudah dan langsung diterima oleh pikiran bawah sadar. Semakin banyak informasi diterima, dan semakin matang sistem kepercayaan dan pola pikir yang terbentuk maka semakin jelas tindakan, kebiasaan, dan karakterunik dari diri masing-masing individu. Dengan kata lain, individu akhirnya memiliki sistem kepercayaan (belief system), citra diri (self image) dan kebiasaan (habit). Jika sistem kepercayaannya benar dan selaras dengan prinsip-prinsip hukum universal maka karakter dan konsep diri yang dimiliki akan baik, akan tetapi sebaliknya kalau sistem kepercayaan salah atau tidak selaras dengan prinsipprinsip hukum universal maka akan berpengaruh terhadap karakter dan konsep diri yang keliru juga.

Dalam Islam, ditemukan bahwa faktor gen/keturunan diakui sebagai salah satu faktor yang mempengaruhi pembentukan karakter. Misalnya, dalam memilih calon pasangan/istri berdasarkan Hadis Nabi Muhammad Saw. adalah dengan berdasarkan kepada 4 (empat) faktor yaitu harta, rupa, keturunan/nasab dan agama. Walaupun faktor keturunan menjadi penting untuk dipertimbangkan dalam memilih seorang istri/pasangan, Rasulullah Saw. mengingatkan bahwa agama menjadi faktor paling penting/utama yang harus dipilih. Seseorang memiliki pemahaman agama yang baik memiliki kecenderungan akhlak yang baik pula karena kedalaman ilmu agama yang dimiliknya sehingga menjadi pedoman dalam setiap perilaku kehidupannya.

\section{Tahap-tahap Pendidikan Karakter}

Secara teoretik, nilai moral/karakter akan berkembang secara psikologis dalam diri individu sesuai perkembangan usia dan konteks sosial. Dalam kaitanya dengan perkembangan usia, Piaget merumuskan perkembangan kesadaran dan pelaksanaan aturan dalam dua domain yaitu kesadaran aturan dan pelaksanaan aturan dengan berbagai tahapannya yaitu:

a. Tahapan pada domain kesadaran aturan

- Usia 0-2 tahun: aturan dirasakan sebagai hal yang tidak bersifat memaksa

- Usia 2-8 tahun: aturan disikapi bersifat sakral dan diterima tanpa pemikiran

- Usia 8-12 tahun: aturan diterima sebagai hasil kesepakatan

b. Tahapan pada domain pelaksanaan aturan

- Usia 0-2 tahun: aturan diterima hanya bersifat motorik

- Usia 2-6 tahun: aturan diterima dengan orientasi diri sendiri

- Usia 6-10 tahun: aturan dilakukan sesuai kesepakatan 
- Usia 10-12 tahun: aturan dilakukan karena sudah terhimpun

Berdasarkan teori tersebut pendidikan sekolah seyogyanya menitikberatkan pada pengembangan kemampuan pengambilan keputusan (decision making skills) dan memecahkan masalah (problem solving) dan membina perkembangan moral dengan cara menuntut peserta didik untuk mengembangkan aturan berdasarkan keadilan/kepatutan.

Dalam pandangan Islam, tahapa perkembangan dan pembentukan karakter dimulai sedini mungkin. Sebagaimana Hadis Rasulullah Muhammad Saw. yang menyatakan:

"Jadikanlah kata-kata pertama yang diucapkan seorang anak kalimat La Ilaha Illallah. Dan bacakan kepadanya menjelang maut kalimat La Ilaha Illallah". (HR. Ibnu Abbās)

"Muliakanlah anak-anakmu dan didiklah mereka dengan adab (budi pekerti) yang baik". (HR. Ibnu Majāh)

"Anak-anak itu pada hari ketujuh dari kelahirannya disembelihkan akikahnya, serta diberi nama dan disingkirkan dari segala kotorankotoran. Jika ia telah berumur 6 tahun ia dididik beradab susila, jika ia berumur 9 tahun dipisahkan tempat tidurnya dan jika berumur 13 tahun dipukul agar mau shalat (diharuskan). Jika ia telah berumur 16 tahun oleh dikawinkan, setelah itu ayah berjabatan tangan dengannya dan mengatakan: "saya telah mendidik, mengajar, dan mengawinkan kamu, saya mohon perlindungan kepada Allah SWT dari fitnah-fitnahan di dunia dan siksaan di akherat." (HR. Ibnu Hibbān dari Anas ra).

Berdasarkan beberapa Hadis di atas, pendidikan karakter dapat diklasifikasikan dalam tahap-tahap berikut:

a. Tauhid (dimulai sejak 0-2 tahun)

b. Adab (5-6 tahun)

c. Tanggung jawab diri (7-8 tahun)

d. Caring-Peduli (9-10 tahun)

e. Kemandirian (11-12 tahun)

f. Bermasyarakat (13 tahun ke atas)

\section{Pilar-pilar Pendidikan Karakter}

\section{a. Moral Knowing}

William Kilpatrick menyebutkan salah satu penyebab ketidakmampuan seseorang berlaku baik meskipun ia telah memiliki pengetahuan tentang kebaikan itu (moral knowing) adalah karena ia tidak berlatih untuk melakukan kebaikan (moral doing). Berdasarkan pemikiran tersebut, kesuksesan pendidikan karakter sangat tergantung pada knowing, loving, dan doing/acting. Moral knowing sebagai aspek utama memiliki enam unsur yaitu: 1) kesadaran moral, 2) pengetahuan tentang nilai-nilai moral, 3) penentuan sudut pandang, 4) logika moral, 5) keberanian mengambil keputusan dan 6) pengenalan diri.

\section{b. Moral Loving/Moral Feeling}

Seseorang yang memiliki kemampuan moral kognitif yang baik, tidak saja menguasai bidangnya, tetapi memiliki dimensi rohani yang kuat. Keputusan-keputusannya menunjukkan warna kemahiran seorang profesional yang didasarkan pada sikap moral/akhlak yang luhur. Moral loving 
merupakan penguatan aspek emosi siswa untuk menjadi manusia berkarakter. Penguatan ini berkaitan dengan bentuk-bentuk sikap yang harus dirasakan siswa, yaitu kesadaran akan jati diri meliputi: 1) percaya diri (self esteem), 2) kepekaan terhadap derita orang lain (emphaty), 3) cinta kebenaran (loving the good), 4) pengendalian diri (self control), dan 5) kerendahan hati (humality).

\section{c. Moral Doing/Acting}

Sebaik-baik manusia adalah yang paling banyak manfaatnya bagi orang lain. Hadis Rasulullah Saw, tersebut mengisyaratkan bahwa seseorang tidak akan memiliki kualitas pribadi yang baik kecuali dengan berbuat sesuatu yang bermanfaat untuk orang lain. Untuk dapat memberikan manfaat yang banyak bagi orang lain, seseorang harus memiliki kemampuan/kompetensi dan keterampilan. Moral acting merupakan outcome yang daharapkan setelah siswa memiliki moral knowing dan moral moral loving.

\section{Ciri Dasar Pendidikan karakter}

Menurut Foerster ada empat ciri dasar dalam pendidikan karakter:

a. Keteraturan interior dimana setiap tindakan diukur berdasarkan hlerarki nilai. Nilai menjadi pedoman normatif setiap tindakan

b. Koherensi yang memberi keberanian seseorang teguh pada prinsip, dan tidak mudah terombang-ambing pada situasi baru atau takut resiko. Koherensi merupakan dasar membangun rasa percaya satu sama lain dan apabila tidak ada dapat meruntuhkan kredibilitas seseorang.

c. Otonomi, dimana seseorang menginternalisasikan aturan dari luar sampai menjadi nilai-nilai pribadi. Ini dapat dilihat melalui penilaian atas keputusan pribadi tanpa terpengaruh desakan pihak lain.

d. Keteguhan dan kesetiaan. Keteguhan merupakan daya tahan seseorang guna menginginkan apa yang dipandang baik. Sedangkan kesetiaan merupakan dasar bagi penghormatan atas komitmen yang dipilih.

\section{Karakter dalam Perspektif Islam}

Dalam diskursus pendidikan karakter mengisyaratkan bahwa spiritualitas dan nilai-nilai agama tidak bisa dipisahkan dari pendidikan karakter. Moral dan nilai-nilai spiritual sangat fundamental dalam membangun kesejahteraan dalam organisasi sosial. Tanpa keduanya, maka elemen vital yang mengikat kehidupan masyarakat dapat dipastikan akan lenyap.

Dalam Islam, tidak ada satu disiplin ilmu apapun yang terpisah dari etika-etika Islam. Ada tiga nilai utama dalam Islam yaitu akhlak, adab dan keteladanan. Akhlak merujuk pada tugas dan tanggung jawab selain syariah dan ajaran Islam secara umum. Adab merujuk pada sikap yang dihubungkan dengan tingkah laku yang baik. Sedangkan keteladanan merujuk pada kualitas karakter yang ditampilkan seorang muslim yang baik yang mengikuti keteladanan Rasulullah Muhammad Saw. 
Moral, karakter, akhlak merupakan istilah yang berbeda akan tetapi memiliki kemiripan makna untuk menunjukkan penanaman dan pengamalan nilai-nilai yang baik selaras dengan prinsip hukum universal. Dalam Islam, karakter disebut juga sebagai akhlak. Hal ini seperti dikemukakan oleh Ahmad Tafsir yang menyatakan bahwa "Karakter itu sama dengan akhlak dalam pandangan Islam. Akhlak dalam pandangan Islam adalah kepribadian yang komponennya adalah tahu (pengetahuan), sikap dan perilaku".

Prinip akhlak Islami termanifestasi dalam aspek kehidupan yang diwarnai keseimbangan, realis, efektif, efisien, azas manfaat, disiplin, dan terencana serta memiliki dasar analisis yang cermat. Kualitas akhlak seseorang dinilai dari tiga indikator yaitu: 1) konsistensi antara yang dilakukan dan perbuatan, 2) konsistensi orientasi, yakni adanya kesesuaian antara pandangan dalam satu hal dengan pandangannya dalam bidang yang lain, dan 3) konsistensi pola hidup sederhana (Mubarok, 2001:20). Dalam tasawuf sikap mental yang selalu memelihara kesucian diri, beribadah, hidup sederhana, rela berkorban untuk kebaikan, dan selalu bersikap kebajikan pada hakikatnya adalah cerminan dari akhlak yang mulia.

Pendidikan karakter dalam Islam pada dasarnya merupakan pendidikan akhlak. Pendidikan akhlak ini, lebih menitikberatkan pada sikap atau kehendak positif yang dibiasakan, sehingga mampu menimbulkan perbuatan positif dengan mudah/automaticly, tanpa melalui pertimbangan pemikiran terlebih dahulu dalam penerapan kehidupan sehari-hari.
Pendidikan karakter Islam memiliki keunikan dan perbedaan dibandingkan pendidikan karakter dari Barat. Pendidikan karakter Islam identik dengan ajaran agama Islam itu sendiri. Perbedaan dengan pendidikan karakter di Barat mencakup penekanan terhadap prinsip-prinsip agama yang abadi, aturan dan hukum dalam memperkuat moralitas, perbedaan pemahaman tentang kebenaran, penolakan terhadap otonomi moral sebagai tujuan pendidikan moral dan penekanan pahala di akherat sebagai motivasi perilaku bermoral. Sumber hukum dan rambu-rambu pendidikan karakter Islam adalah wahyu Alquran dan Hadis.

Alquran banyak mengaitkan akhlak terhadap Allah dengan akhlak kepada Rasulullah. Sebelum seorang muslim yang memiliki karakter mulia kepada diri dan sesamanya, terlebih dahulu harus memulainya dengan berkarakter mulia kepada Allah dan Rasulullah. Kualitas cinta kepada sesama tidak boleh melebihi kualitas cinta kepada Allah dan Rasulullah (QS al-Tawbah [9]: 24). Bentuk karakter mulia terhadap Allah Swt, adalah dengan mengikuti perintah dan menjauhi segala larangan-Nya.

Karakter mulia terhadap Rasulullah adalah taat kepadanya dan mengikuti sunnahnya (QS. al-Nisā' [4]: 59), serta mengucapkan shalawat dan salam kepadanya (QS. al-Aḥzāb [33]: 56). Keharusan menjunjung tinggi karakter mulia (akhlāq karīmah) lebih dipertegas lagi oleh Nabi Muhammad Saw. dengan seperti diriwayatkan oleh Abdullah Ibn Amr: "Sebaik-baik kamu adalah yang paling baik akhlaknya ..." (HR. alTirmidzi). Dengan demikian, dapat dinyatakan bahwa karakter mulia dalam perspektif Islam merupakan sistem 
perilaku yang diwajibkan dalam agama Islam yang tertuang melalui nash Alquran dan Hadis.

\section{Peran Pendidikan Agama dalam Pembentukan Karakter}

Mantan Presiden RI pertama Soekarno berulang-ulang menegaskan bahwa, "Agama adalah unsur mutlak dalam National and Character Building". Tanpa landasan yang jelas, karakter kemandirian tidak punya arah, mengambang, keropos dan tidak berarti apa-apa. Untuk itu, fundamen/landasan yang kokoh dari pendidikan karakter adalah agama.

Thomas Lickona, memiliki pandangan yang memisahkan antara pendidikan karakter dan pendidikan agama. Kehidupan religius seseorang merupakan urusan antara individu dengan Tuhannya. Karakter tidak ada hubungannya dengan ibadat dan doadoa di sekolah. Karakter adalah nilainilai dasar yang harus dihayati jika sebuah masyarakat mau hidup dan bekerja secara damai. Nilai-nilai tersebut seperti kebijaksanaan, penghormatan terhadap orang lain, tanggung jawab pribadi, perasaan senasib sepenanggungan, pemecahan konflik secara damai adalah sebagian contoh nilai-nilai karakter. Pemikiran Thomas Lickona ini berbeda dengan pendidikan karakter Islam yang menjadikan agama sebagai fondasi dalam melaksanakannya.

\section{Prinsip Pendidikan Karakter}

Character education quality standards merekomendasikan 11 prinsip untuk mewujudkan pendidikan karakter yang efektif, yaitu: a. Mempromosikan nilai-nilai dasar etika sebagai basis karakter

b. Mengidentifikasi karakter secara komprehensif supaya mencakup pemikiran, perasaan dan perilaku.

c. Menggunakan pendekatan yang tajam, proaktif dan efektif untuk membagun karakter

d. Menciptakan komunitas sekolah yang memiliki kepedulian

e. Memberi kesempatan kepada siswa untuk menunjukkan perilaku yang baik

f. Memiliki cakupan terhadap kurikulum yang bermakna dan menantang yang menghargai semua siswa, membangun karakter mereka, dan membantu mereka

g. Mengusahakan tumbuhnya motivasi diri dari para siswa

h. Memfungsikan seluruh staf sekolah sebagai komunitas moral yang berbagi tanggungjawab untuk pendidikan karakter dan setia kepada nilai dasar yang sama.

i. Adanya pembagian kepemimpinan moral dan dukungan yang luas dalam membangun inisiatif pendidikan karakter.

j. Memfungsikan keluarga dan anggota masyarakat sebagai mitra dalam usaha membangun karakter.

k. Mengevaluasi karakter sekolah, fungsi staf sekolah sebagai guru-guru karakter dan manifestasi karakter positif dalam kehidupan siswa.

Berdasarkan prinsip-prinsip tersebut, program pendidikan karakter di sekolah dapat dikembangkan. Tidak 
kalah pentingnya adalah keteladanan Rasullulah Saw. dalam menanamkan keimanan dan akhlak yang baik juga dijadikan prinsip dalam mengembangkan pendidikan karakter di sekolah. Adapun prinsip-prinsip tertsebut diantaranya:

a. Fokus, ucapannya ringkas, langsung pada inti pembicaraan tanpa ada kata yang dapat memalingkan dari ucapannya, sehingga mudah dipahami.

b. Pembicaraannya tidak terlalu cepat sehingga dapat memberikan waktu yang cukup kepada anak untuk menguasainya.

c. Repetisi, senantiasa melakukan tiga kali pengulangan pada kalimat-kalimatnya supaya dapat diingat atau dihafal.

d. Memberikan analogi langsung.

e. Memperhatikan keragaman anak sehingga melahirkan pemahaman yang berbeda dan tidak terbatas satu pemahaman saja dan dapat memotivasi siswa untuk terus belajar tanpa dihinggapi perasaan jemu.

f. Memperhatikan tiga tujuan moral yaitu: kognitif, mosional dan kinetik.

g. Memperhatikan pertumbuhan dan perkembangan anak.

h. Menumbuhkan kreativitas anak dengan cara mengajukan pertanyaan kemudian mendapat jawaban dari anak yang diajak bicara.

i. Berbaur dengan anak-anak, masyarakar dan lain sebagainya.

j. Aplikatif, yaitu Rasulullah langsung memberikan pekerjaan kepada anak yang berbakat.

\section{Strategi dan Model Pendidikan Karakter}

Menurut Brooks dan Goole (Mubarak, 2009:12) untuk mengimplementasikan pendidikan karakter di sekolah terdapat tiga elemen penting untuk diperhatikan, yaitu prinsip, proses dan praktiknya. Dalam menjalankan prinsip, nilai-nilai yang diajarkan harus termanifestasikan dalam kurikulum sehingga semua siswa di suatu sekolah faham benar tentang nilai-nilai tersebut dan mampu menerjemahkannya dalam prilaku nyata. Strategi dalam melaksanakan pendidikan karakter melalui tiga tahap yaitu 1) Moral knowing/learning to know, 2) Moral loving/Moral feeling, dan 3) Moral doing/learning to do.

Model internalisasi pendidikan karakter dapat dengan model: 1) tadzkirah yaitu suatu model yang menghantarkan murid agar senantiasa memupuk, memelihara dan menumbuhkan rasa keimanan yang telah diilhamkan oleh Allah Swt. agar terwujud ke dalam amal saleh yang dibingkai dengan ibadah yang ikhlas sehingga melahirkan suasana hati yang lapang dan ridha atas ketetapan Allah SWT. 2) Model selanjutnya adalah melalui keteladanan, 3) melaui bimbingan/ arahan, 4) melalui dorongan/ motivasi, 5) melaui zakiyah/mensucikan diri, 6) melalui pengorganisasian, 10) melalui hati, dan 11) melalui model iqra, fikir, dzikir.

Strategi dan model penerapan pendidikan karakter sangat tergantung pada kondisi indivisu, organisasi maupun lingkungan sekitarnya. Semakin kuat motivasi yang ada dalam diri individu dalam menerapkan pendidikan karekter, maka faktor eksternal menjadi pendukung dalam 
mengimplementasikannya sehingga ketika dilaksanakan secara bersamasama dalam suatu organisasi akan membentuk budaya organisasi yang seperti diharapkan oleh semua pihak. Salah satu strategi implementasi pendidikan karakter yang cukup efektif seperti diterapkan oleh Abdullah Gymnastiar tokoh ulama pendiri lembaga pendidikan Daruttauhid Bandung adalah melalui $3 \mathrm{M}$ meliputi: 1) mulai dari diri sendiri, 2) mulai dari yang tekecil, dan 3) mulai saat ini juga. Hal ini berarti bahwa peran individu dalam menginternalisasi nilai-nilai karakter sangat penting dan menjadi hal yang utama.

Selain motivasi yang kuat dari dalam diri individu, internalisasi karakter perlu disesuaikan dengan kondisi real lapangan yang dihadapi. Karakter generasi millennial yang kritis dan selalu ingin tahu berbeda dengan generasi pasca bomber atau generasi sebelum era millennial. Untuk itu, Karakter yang ditanamkan harus selaras dengan apa yang menjadi tantangan hidup era millennial.

Framework generasi millenial menurut (BSNP:2010) adalah sebagai berikut: (a) Kemampuan berpikir kritis dan pemecahan masalah (criticalthinking and problem-solving skills), mampu berfikir secara kritis, lateral, dan sistemik, terutama dalam konteks pemecahan masalah; (b) Kemampuan berkomunikasi dan bekerjasama (communication and collaboration skills), mampu berkomunikasi dan berkolaborasi secara efektif dengan berbagai pihak; (c) Kemampuan berpikir kritis dan pemecahan masalah (criticalthinking and problem-solving skills), mampu berfikir secara kritis, lateral, dan sistemik, terutama dalam konteks pemecahan masalah; (d) Kemampuan berkomunikasi dan bekerjasama (communication and collaboration skills), mampu berkomunikasi dan berkolaborasi secara efektif dengan berbagai pihak; (e) Kemampuan mencipta dan membaharui (creativity and innovation skills), mampu mengembangkan kreativitas yang dimilikinya untuk menghasilkan berbagai terobosan yang inovatif; ( $f$ ) Literasi teknologi informasi dan komunikasi (information and communications technology literacy), mampu memanfaatkan teknologi informasi dan komunikasi untuk meningkatkan kinerja dan aktivitas sehari-hari; (g) Kemampuan belajar kontekstual (contextual learning skills), mampu menjalani aktivitas pembelajaran mandiri yang kontekstual sebagai bagian dari pengembangan pribadi, dan (h) Kemampuan informasi dan literasi media sehingga mampu memahami dan menggunakan berbagai media komunikasi untuk menyampaikan beragam gagasan dan melaksanakan aktivitas kolaborasi serta interaksi dengan beragam pihak.

Model dan strategi dalam memberikan penamaman nilai karakter maupun pengetahuan kognitif disesuaikan dengan kondisi dan zaman yang ada serta dimulai sedini mungkin, relevan dengan pernyataan Sayyidina Ali bin Abi Thalib sahabat Rasulullah sebagai berikut:

"Janganlah engkau memaksakan anak-anakmu sesuai dengan pendidikanmu, karena sesungguhnya mereka diciptakan untuk zaman yang bukan zaman kalian. Cetaklah tanah selama ia masih basah dan tanamlah kayu 
selama ia masih lunak". (Syaikh Fadlullah, 1998:153).

Hal ini berarti pula bahwa penanaman nilai-nilai karakter harus dilakukan sejak usia dini. Usia dini diibaratkan tanah liat yang masih mudah dibentuk, sehingga mudah diberikan pendidikan sesuai apa yang diharapkan. Usia dini juga dikenal golden ages yang merupakan usia emas untuk berkembangnya kecerdasan baik secara intelektual maupun emosialnya. Pada usia dini, kemampuan mengingat dan menangkap pengetahuan yang diberikan juga masih sangat kuat, sehingga memungkinkan anak mempelajari semua hal yang diberikan oleh sumber belajarnya.

\section{PENUTUP}

\section{Simpulan}

Moral, karakter, akhlak merupakan istilah yang berbeda akan tetapi memiliki kemiripan makna untuk menunjukkan penanaman dan pengamalan nilai-nilai yang baik selaras dengan prinsip hukum universal.

Dalam pandangan Islam, karakter disebut juga dengan akhlak. Hal ini didukung oleh pakar pendidikan karakter Ahmad Tafsir yang menyatakan bahwa "karakter itu sama dengan akhlak dalam pandangan Islam. Akhlak dalam pandangan Islam adalah kepribadian yang komponennya adalah tahu (pengetahuan), sikap dan perilaku".

Prinip akhlak Islami termanifestasi dalam aspek kehidupan yang diwarnai keseimbangan, realis, efektif, efisien, azas manfaat, disiplin, dan terencana serta memiliki dasar analisis yang cermat. Kualitas akhlak seseorang dinilai dari tiga indikator yaitu: 1) konsistensi antara yang dilakukan dan perbuatan, 2) konsistensi orientasi, yakni adanya kesesuaian antara pandangan dalam satu hal dengan pandangannya dalam bidang yang lain, dan 3) konsistensi pola hidup sederhana. Dalam tasawuf sikap mental yang selalu memelihara kesucian diri, beribadah, hidup sederhana, rela berkorban untuk kebaikan, dan selalu bersikap kebajikan pada hakikatnya adalah cerminan dari akhlak yang mulia.

Komponen pendidikan akhlak meliputi: pengetahuan, sikap, dan perilaku dan identik dengan ajaran agama Islam itu sendiri yang bersumber dari Alquran dan al-Hadis. Dengan demikian, dapat dinyatakan bahwa pendidikan karakter perspektif Islam merupakan sistem perilaku yang diwajibkan dalam agama Islam yang tertuang melalui nash Alquran dan Hadis.

Dalam melaksanakan pendidikan karakter, akan lebih terinternalisasi ketika prinsip-prinsip pendidikan karakter dapat diintegrasikan dengan nilai-nilai religiusitas/ajaran agama. Dengan demikian, nilai-nilai yang akan diajarkan harus termanifestasikan dalam kurikulum sehingga semua siswa di suatu sekolah faham benar tentang nilai-nilai tersebut dan mampu menerjemahkannya dalam prilaku nyata. Strategi dalam melaksanakan pendidikan karakter dapat melalui tiga tahap yaitu 1) Moral Knowing/Learning to Know, 2) Moral Loving/Moral Feeling, dan 3) Moral Doing/Learning to do. Sedangkan implementasi pendidikan karakter dalam Islam menurut hadis Rasulullah Saw, dapat diklasifikasikan dalam 6 tahapan yaitu: 1) Tauhid (dimulai sejak 0-2 tahun); 2) Adab (5-6 tahun); 3) Tanggung jawab diri (7-8 
tahun); 4) Caring-Peduli (9-10 tahun); 5) Kemandirian (11-12 tahun); dan 6) Bermasyarakat (13 tahun ke atas).

\section{Rekomendasi}

Pendidikan karakter, akan lebih terinternalisasi ketika prinsip-prinsip pendidikan karakter dapat diintegrasikan dengan nilai-nilai religiusitas/ajaran agama. Untuk itu, perlu kesadaran semua pihak untuk merevitalisasi pendidikan agama mulai dari unit Pendidikan yaitu terkecil yaitu keluarga, kemudian dilaksanakan di masyarakat, bangsa dan negara.

\section{DAFTAR PUSTAKA}

Badan Standar Nasional Pendidikan (BSNP). (2010). Laporan BSNP Tahun 2010. Jakarta: Badan Standar Nasional Pendidikan (BSNP). Retrieved from http://www.bsnpindonesia.org/id/wp-content/uploads/2012/04/Laporan-BSNP-2010.pdf

Departemen Agama RI. (1984). Alquran dan Terjemahannya. Jakarta: Departemen Agama RI.

Gunawan, A. W. (2006). Hypnosys-The Art of Subconscious Communication. Jakarta: PT. Gramedia Pustaka Utama.

Hafiduddin, D. (2002). Membentuk Pribadi Qur'an. Bandung: Harakah.

Hamzah, Y. (1983). Etika Islam.

Hasan, M. (2002). Pokok-pokok Materi Metodologi Penelitian. Jakarta: Ghalia Indonesia.

Komidar, J. (1995). Use of Library. Dalam S. Harahap, Metodologi Studi dan Penelitian Ilmu-ilmu Ushuluddin. Jakarta: Rajawali Press.

Lickona, T. (1991). Educating for Character. New York: Bantam.

Lickona, T. (1999). Religion and Character Education. Phe Delta Kppan.

Majid, A., \& Andayani, D. (2013). Pendidikan Karakter Perspektif Islam (Ketiga ed.). Bandung: PT. Remaja Rosdakarya.

Marzuki. (2009). Prinsip Dasar Akhlak Mulia: Pengantar Studi Konsep-Konsep Dasar Etika dalam Islam. Yogyakarta: Dsebut Wahana Press-FISE UNY.

Murphy, J. (2002). Rahasia Kekuatan Pikiran Bawah Sadar. Jakarta: Spektrum.

Pusat Bahasa Departemen Pendidikan Nasional. (2008). Kamus Besar Bahasa Indonesia (Keempat ed.). Jakarta: PT. Gramedia Pustaka Utama.

Samani, M., \& Hariyanto. (2011). Konsep dan Model Pendidikan Karakter. Bandung: PT. Remaja Rosdakarya.

Ubabuddin. (2018). Konsep Pendidikan Karakter Perspektif Islam. Ta'dib: Jurnal Pendidikan Islam, 7(1), 454-460. Dipetik dari from https://ejournal.unisba.ac.id/index.php/tadib/article/view/3428/2256 
UNESCO-UNEVOC. (2005). Learning to Do (Values for Learning and Working Together in a Globalized World. Germany.

Undang-undang RI Nomor 20 Tahun 2003 tentang Sistem Pendidikan Nasional 